International Journal of Heritage, Tourism and Hospitality

journal homepage: https://ijhth.journals.ekb.eg

\title{
Transformational leadership and its relationship with the empowerment of employees in The Egyptian travel agencies
}

Yasmine Hassan Mohamed Ali ${ }^{\mathrm{a}}$, Alfatma Fathalla Salama ${ }^{\mathrm{a}}$, Mohammad Farrag ${ }^{\mathrm{b}}$

${ }^{a}$ Faculty of Hospitality and Tourism, Minia University, Egypt

${ }^{b}$ Faculty of Tourism and Hotels, Fayoum University, Egypt

\begin{tabular}{l}
\hline ARTICLE INFO. \\
\hline Keywords: \\
Transformational Leadership, \\
Empowerment, \\
Inspirational Motivation, \\
Attractiveness, \\
Leader.
\end{tabular}

\section{Introduction}

Leadership is an important factor that influences followers' attitudes and behaviors toward the organizational goals. It always articulates future visions, supports to build up one-to-one relationships and raise the interest of followers. However, transformational leadership is concerned with the creative and innovative aspects of employees and organizations.

Employees' creativity is known as an important factor for the organizational goals. It supports individuals to existing and foresees problems with the remedies through leadership creative ideas, thinking and experience. On the contrary, transformational leadership creates selfconfidence, intrinsic motivation, inspirations, and creative endeavors and supports innovation, personal development, and social relationships among employees (Gumusluoglu and Ilsev, 2009). management is one of the most important areas that is affected by global changes at the level of the state and organization and imposed the urgent need to face these challenges, distinction in the leading style and superiority in the fields of research and development, concern about the quality in the production of goods and services, and the transition and management methods from local to global. Leadership is an important and necessary to achieve organization goals, and managers, whether they are at the high management, middle or direct level, can positively or negatively influence the attitudes and expectations of their subordinates, they can encourage or frustrate them, and they can deepen their loyalty or dispel it (Avolio et al., 2009).

With the accelerated processes of change and diversity of areas and the emergence of many of the repercussions on the organizations in the nineties, it directed research and scientific studies towards the study of change, and how to manage it to achieve survival and continuity and competition for organizations and brought out many theories and models in the management leadership, the most important theory of transformational leadership (Arnold and Loughlin, 2013).

${ }^{1}$ Corresponding author, email: jasminehassan240@gmail.com 
One of the most important distinction styles of transformational leadership is its global ability to lead the organization in facing of modern challenges and developments by influencing subordinates' behaviors and developing their creative abilities by opening the field up for them and encouraging them to face the problems and difficulties facing their organizations (Judge et al., 2004).

Leaders who have transformational behavior have the power to provide subordinates with energy and inspiration to enable them to act by providing them with a vision for the future instead of relying on punishment and rewards. Transformational leadership changes their ability to create behavior that enhances the self-efficacy and motivation of workers.

As the tourism organization are a vital tool in the human societies, the leaders of these organizations are the pivotal element in achieving the goals and objectives related to the adequacy and efficiency desired, and this requires them to provide special abilities and requirements to be able to cope with changes and transfers contemporary and dealing with it capability and efficiently.

\subsection{The Research Hypotheses}

a. There is a statistically significant relationship between inspirational motivation and empowerment of employees within Egyptian tourism companies category A

b. There is a statistically significant relationship between the attractiveness of the leader and the empowerment of employees in the Egyptian travel agencies category A.

\subsection{The Research Objectives}

- Identify the relationship of motivation and inspire the empowerment of Employees in the Egyptian travel agencies.

- Examining the relationship between intellectual stimulation and the empowerment of Employees in the Egyptian travel agencies.

- To determine the relationship between individual considerations and the empowerment of Employees in the Egyptian travel agencies.

\subsection{The Research importance}

The impotence of the research stems from the importance of the topic that will be addressed, namely transformational leadership and its relationship with the empowerment of Employees in The Egyptian Travel Agencies. This is the first topic in Egypt that examines the relationship between transformational leadership and the empowerment of workers in tourism institutions. This study may help the leaders of tourism institutions to shed light on the importance of human resources as strategic assets for tourism organization and the importance of empowering employees and introducing them to a new style of leadership, namely transformational leadership and supporting these leaders to change their leadership styles as an essential step to empower their employees.

\section{Literature review}

Leadership plays a necessary role in determining the failure and success of a firm (Lim and Ployhart, 2004). Gillespie et al. (2004) identified that leaders help to motivate, stimulate, recognize, and encourage their followers in order to get key performance results. There are a lot of different styles of leadership. (McCan et al., 2003) has pointed out following styles of leadership: bureaucratic, autocratic, charismatic, laissez-faire, democratic, situational, participative, transactional, and transformational leadership.

\subsection{Transformational leadership}

Schepers et al. (2005) claimed that transformational leaders allowed workers to think creatively, analyzed the problem from many angles and explored new and better solutions of the problem by using technology. Organizations can reduce task stress and burn out by applying transformational leadership.

\subsection{Transformational Leadership Dimensions}

According to Bass (1998), (Bass and Riggio, 2006; Northouse, 2013) and (Bass et al., 2003; Yammarino et al., 2002) there are four dimensions of Transformational Leadership:

1. Idealized influence: the leader acts in ways that result in being a role model for the followers. Therefore, the leader becomes venerated, respected, and trusted by the followers who want to emulate them. The followers also recognize strange capabilities, persistence, and determination in the leader. It is also evident that the leader is willing to take risks to achieve goals but assumes an ethical and moral comportment for that. 
2. Inspirational motivation means that the leader behaves enthusiastically and optimistically. They share positive future visions, display confidence, and communicate expectations, which subordinates want to meet due to the motivating behaviors that their leader has displayed.

3. Intellectual stimulation is especially focused on stimulating subordinates' innovativeness and creativity. Such subordinates question the assumptions and values of themselves, their leaders, and their organizations. They seek to reframe problems, approach old situations in new ways, and try creative solutions and they do not criticize others for making mistakes or having differing opinions.

4. Individualized consideration. The leader attends to each follower's need for accomplishment and growth by acting as coach or mentor. The leader tries to create new learning opportunities in a supportive climate; so, the leader demonstrates acceptance for individual differences, have confirmed communication with the followers, adopts an active listening style, and delegates tasks to develop followers' skills.

\subsection{Applying Transformational Leadership}

Because transformational leadership covers a wide range of aspects within leadership, there are no specific steps for a manager to follow. Becoming an effective transformational leader is a process. This means that conscious effort must be made to accept a transformational style. (Northouse, 2001). A transformational leader has the following qualities According to Northouse (2001):

- Creates a vision, using people in the organization.

- Acts as a change agent within the organization by setting an example of how to initiate and implement change.

- Empowers followers to do what is best for the organization.

- A strong role model within height values.

- Listens to all viewpoints to develop a spirit of cooperation.

- Helps the organization by helping others contribute to the organization.

\subsection{Employee empowerment}

Conger and Kanungo (1988) viewed empowerment as a motivational (desire to do something/reason for doing something) construct. So empowerment is an enabling rather than a delegating process. Enabling, from this perspective, involves creating conditions for enhancing motivation for task accomplishment through the development of a strong sense of personal efficacy. Empowerment becomes a process of improving feelings of selfeffectiveness among organizational members through the identification of conditions that develop powerlessness and through their removal by both informal organizational practices and formal. Provides encouragement to some followers, values patterns of work to others, and provides autonomy to those with more experience. In this way, the leader establishes two-way exchange processes of ways of doing things of providing effectiveness information.

\subsection{Dimensions of empowerment}

The scale used to measure empowerment was at first published by Spreitzer (1995). The 12- item empowerment scale makes up of four dimensions:

- Meaning: refers to the value of purpose or a work goal, judged in relation to one's own thinking or principles.

- Competence: is person's belief in his capability to complete activities with skill.

- Self-determination: refers to people sense that they have a choice in initiating and regulating actions.

- Impact: is the degree to which an individual can influence strategic, administrative, or operating results at work.

\subsection{Measuring empowerments}

From the point of view of the individual employee, an empowered employee was one who can say:

- I have control over my work and work big picture.

- I have the personal smart ability to do my work.

- I am person- friend energized by the goals of the organization.

Having defined empowerment at the individual level in terms of these three mental dimensions, it was now possible to improve a measure of psychological empowerment. The measure could 
possibly consist of items that capture these three dimensions.

As each of the three dimensions of perceived control, perceived smart ability, and goal internalization is carefully thought about to be conceptually separate, empowerment was conceived as a positive additive function of these dimensions. This treatment assumes that there are no important interactions among these dimensions.

\subsection{The impact of Transformational leadership on employee effectiveness}

Studies have also showed that the positive influences of transformational leadership can apply to different types of organizations, including private enterprise, educational institutions, and the military (Bass et al., 1992; MacKenzie et al., 2000; Podsakoff et al., 1990; Stone, 1992).

Among different indicators of effective transformational leadership, organizational commitment, or loyalty, is the most important. The first goal of transformational leadership is to communicate the organization's vision to subordinates and to encourage them to reserve extra effort to accomplishing organizational goals. Anyway, the loyalty of assistants or organizational commitment is the most direct indicator of effective transformational leadership (Avolio et al., 2004; Sharmir et al., 1998).

In this study, organizational loyalty is defined as the members' identification with and internalization of the organization's vision, as well as their willingness (state of mind where someone will do something if needed) to sacrifice personal interests for the success of the organization.

This definition includes related to emotions organizational commitment (Meyer and Allen, 1997) and personal sacrifice (Podsakoff et al., 1990). Transformational leadership draws attention to the promotion of personal changes in the interests of facilitating organizational transformation. Hence, personal sacrifice by the organization's members is critical for a successful transformation process. These include delayed reward and losses and time-related inconvenience (Podsakoff et al., 1990).

Recent studies show that the relationship between transformational leadership and related to emotions organizational commitment is positive and strong (Avolio et al., 2004; Spreitzer et al., 2005). Also, studies have indicated that subordinates' trust in supervisor is also a critical indicator of effective transformational leadership (Gillespie and Mann, 2004; Podsakoff et al., 1990).

\section{Methodology}

The Research aims to determine the relationship between individual considerations and the empowerment of Employees in The Egyptian Travel Agencies and Examining the relationship between intellectual stimulation and the empowerment of Employees in The Egyptian Travel Agencies, also Identify the relationship of motivation and inspire the empowerment of Employees in The Egyptian Travel Agencies.

\subsection{Data collection}

The research was conducted with a purpose to investigate the relationship between transformational leadership and empowering the Employees in the Egyptian travel agencies. Consisting of 35 items, divided into four parts was designed. One hundred travel agencies category A were selected on simple random sampling basis. A total 600 questionnaires were circulated, out of which 585 questionnaires returned back, after reviewing these questionnaires, 10 questionnaires were excluded for their lack of statistical analysis, so that the number of valid questionnaires became 575 , with $95.83 \%$ of the total distributed questionnaires.

\subsection{Data analysis}

Survey lists were distributed and collected, and after reviewing these lists, the answers were discharged in the Statistical System (SPSS) in sequence in the survey list. After the end of the discharge, the results were extracted and the relationships between the different variables were found in preparation for the stage of analysis and interpretation followed by the stage of analysis of the data for the study sample with the correlation to the results and then the interpretation of these results. The researcher analyzed all the data using the Statistical Analysis Program (SPSS) where it collected the data, used percentage, Frequencies, and chi square test (Ka2 test).

This test (the relationship between a set of variables in the field study) is illustrated by examining the moral differences between some of these variables through the K2 function (moral level) and clarifying some correlations between a set of important variables in the field study. These relationships were created through the Ka2 test. 
The arithmetic medium of some questions has been calculated in order to find out the average size of the sample tested.

\section{Results}

600 forms were distributed to the employees of tourism companies in Hurghada, Luxor, Sohag, and Cairo and only 585 of them were collected. After reviewing these forms, 10 of them were excluded because they were not suitable for statistical analysis, bringing the number of valid forms to 575 forms at $95.83 \%$ of the total forms distributed.

This list was developed to identify all the data and information about the extent of the application of transformational leadership within the tourism companies and the impact of their application to the employees of the company.

\subsection{Descriptive analysis of variable}

Table 1

Percentage and Iterations of sample type

\begin{tabular}{|l|l|c|c|c|c|}
\hline \multicolumn{2}{|c|}{ Gender } & Frequency & Percent & Valid Percent & Cumulative Percent \\
\hline \multirow{3}{*}{ Valid } & Male & 367 & 63.8 & 64.0 & 64.0 \\
\cline { 2 - 6 } & Female & 206 & 35.8 & 36.0 & 100.0 \\
\cline { 2 - 6 } & Total & 573 & 99.7 & 100.0 & \\
\hline Missing & System & 2 & .3 & & \\
\hline \multicolumn{2}{|l|}{ Total } & 575 & 100.0 & & \\
\hline
\end{tabular}

Table 1 Shows that the number of male sample members was 367 by $63.8 \%$. While the number of females was 206 by $35.8 \%$, this reflects the true representation of females and males in the study community.

\subsection{Scientific qualification}

Table 2

Percentage and Repetitions of the scientific qualification of sample members

\section{Education}

\begin{tabular}{|c|c|c|c|c|c|}
\hline \multicolumn{2}{|c|}{ (n) } & Frequency & Percent & Valid Percent & Cumulative Percent \\
\hline \multirow[t]{5}{*}{ Valid } & Intermediate Qualification & 89 & 15.5 & 15.5 & 15.5 \\
\hline & Bachelor/Bachelor's Degree & 407 & 70.8 & 70.8 & 86.3 \\
\hline & Master/PhD & 67 & 11.7 & 11.7 & 97.9 \\
\hline & Other & 12 & 2.1 & 2.1 & 100.0 \\
\hline & Total & 575 & 100.0 & 100.0 & \\
\hline
\end{tabular}

Previous table (2) shows that there are 89 individuals with $15.5 \%$ of those who occupy (average qualification) while there are 407 individuals with $70.8 \%$ bachelor's degree, while 67 individuals are in the master's and doctoral degrees with $11.7 \%$. For the other level of education other than the previous number 12 by 2.1 , we also note from the following table that tourism companies category (A) employs university graduates (bachelor or bachelor's degree) by a large percentage of which exceeds $70 \%$. This is a positive indicator that enables companies to benefit from their scientific knowledge.

This is also an important indicator that can be more focused on, especially the master's and doctoral ratios in their accreditation in delegation and decision-making.

4.3Years of experience

Table 3

Percentage and Repetitions of the number of years of experience for sample members

\begin{tabular}{|l|l|c|c|c|c|}
\hline \multicolumn{2}{|l|}{ Time } & Frequency & Percent & Valid Percent & Cumulative Percent \\
\hline \multirow{2}{*}{ Valid } & Less 5 years & 157 & 27.3 & 27.3 & 27.3 \\
\cline { 2 - 6 } & 5 to 10 years & 328 & 57.0 & 57.0 & 84.3 \\
\hline
\end{tabular}




\begin{tabular}{|l|l|c|c|c|c|}
\hline \multirow{2}{*}{4.00} & More 10 years & 64 & 11.1 & 11.1 & 95.5 \\
\cline { 2 - 6 } & 4.00 & 4.5 & 4.5 & 100.0 \\
\cline { 2 - 6 } & Total & 575 & 100.0 & 100.0 & \\
\hline
\end{tabular}

It is clear from the previous table 3 that the number of people with more than 10 years of experience is 64 individuals by $11.1 \%$. There are 328 individuals with 5-10 years of experience at $57.0 \%$, while 157 people are under 5 years of age with $27 \%$. All these figures are a strong indicator of the accumulation of knowledge experience in working within

Table 4

Percentage and Repetitions for Age

\begin{tabular}{|c|c|c|c|c|c|}
\hline \multicolumn{6}{|l|}{ Age } \\
\hline & & Frequency & Percent & Valid Percent & Cumulative Percent \\
\hline \multirow[t]{4}{*}{ Valid } & Less 26 & 174 & 30.3 & 30.3 & 30.3 \\
\hline & 26 to 40 & 292 & 50.8 & 50.8 & 81.0 \\
\hline & 41 to 60 & 109 & 19.0 & 19.0 & 100.0 \\
\hline & Total & 575 & 100.0 & 100.0 & \\
\hline
\end{tabular}

Table 4 indicates that there are 174 individuals less than 26 years of age at 30.3. There are also 292 people aged 26 to under 40 at $50.8 \%$. This shows us that the age group that is predominantly employed in Egyptian tourism companies is the Table 5

Kruskal-Wallis test results for the effect of transformative driving on the empowerment of workers within tourism companies (Category A) age variable

\begin{tabular}{|c|c|c|c|c|c|c|c|}
\hline \multicolumn{8}{|l|}{ Ranks } \\
\hline & Age & $\mathbf{N}$ & Mean Rank & Chi-Square & Df & Asymp. Sig & Significance level \\
\hline \multirow{4}{*}{$\begin{array}{l}\text { Idealized } \\
\text { influence }\end{array}$} & Less 26 & 174 & 250.41 & 14.699 & 2 & 0.001 & \multirow{5}{*}{$\begin{array}{l}\text { statistically } \\
\text { significant }\end{array}$} \\
\hline & 26 to 40 & 292 & 303.12 & & & & \\
\hline & 41 to 60 & 109 & 307.51 & & & & \\
\hline & Total & 575 & & & & & \\
\hline \multirow{4}{*}{$\begin{array}{l}\text { Inspirational } \\
\text { motivation }\end{array}$} & Less 26 & 172 & 255.17 & 9.621 & 2 & 0.008 & \\
\hline & 26 to 40 & 291 & 299.24 & & & & \multirow{3}{*}{$\begin{array}{l}\text { statistically } \\
\text { significant }\end{array}$} \\
\hline & 41 to 60 & 109 & 301.93 & & & & \\
\hline & Total & 572 & & & & & \\
\hline \multirow{4}{*}{$\begin{array}{l}\text { Intellectual } \\
\text { stimulation }\end{array}$} & Less 26 & 173 & 256.56 & 8.616 & 2 & 0.013 & \multirow{4}{*}{$\begin{array}{l}\text { statistically } \\
\text { significant }\end{array}$} \\
\hline & 26 to 40 & 290 & 296.01 & & & & \\
\hline & 41 to60 & 108 & 306.29 & & & & \\
\hline & Total & 571 & & & & & \\
\hline \multirow{4}{*}{$\begin{array}{l}\text { Individualized } \\
\text { consideration }\end{array}$} & Less 26 & 173 & 265.18 & 4.915 & 2 & 0.086 & \multirow{4}{*}{$\begin{array}{l}\text { statistically } \\
\text { significant }\end{array}$} \\
\hline & 26 to 40 & 291 & 298.82 & & & & \\
\hline & 41 to60 & 108 & 287.44 & & & & \\
\hline & Total & 572 & & & & & \\
\hline
\end{tabular}

Egyptian tourism companies Category A for sample members. This indicator affects the sincerity of the study's answers because of the abilities and skills that the experience gives to the ease of understanding the variables to be questioned. youth group and the following figure (3) also explains this.

\subsection{Kruskal-Wallis Test}




\begin{tabular}{|l|l|l|l|l|l|l|l|}
\hline Ranks & Age & N & Mean Rank & Chi-Square & Df & Asymp. Sig & Significance level \\
\hline \multirow{3}{*}{26 to 40} & 292 & 299.14 & & & & \\
\cline { 2 - 7 } & 41 to60 & 109 & 315.15 & & & & \\
\cline { 2 - 6 } & Total & 574 & & & & & \\
\hline
\end{tabular}

Table (5) shows that there are statistically significant differences in the dimensions of the study, and to determine the sources of statistically functioning differences for the responses of the study sample to the variable of age and the table explains the following:

There are statistically significant differences between the responses of the study sample in terms of the leader's inspirational motivation as one of the dimensions of the study. The differences were in favor of age from 41 to 60 , followed by 26 to 40, followed by less than 26 .

There were statistically significant differences between the responses of the study sample in terms of intellectual stimulation as one of the dimensions of the study and the differences in favor of age from 41 to 60 followed by 26 to 40 followed by less than 26 .

There are statistically significant differences between the study sample responses in terms of the degrees of empowerment of workers within tourism companies Category $\mathrm{A}$ as one of the dimensions of the study. The differences were in favor of ages 26 to 40 , followed by 41 to 60 , followed by less than 26 .

\subsection{Testing the hypotheses of the study}

There is a statistically significant relationship between the Transformation leadership in empowering the employees in The Egyptian travel agencies). And to verify the validity of this imposition has been divided into four subhypotheses as follows:

H1: There is a statistically significant relationship between the attractiveness of the leader and the empowerment of Employees in The Egyptian travel agencies category A.

\section{Table 6}

Results of attractive impact test on employee empowerment.

\begin{tabular}{|l|c|c|c|c|c|}
\hline \multicolumn{1}{|c|}{ Model } & $\begin{array}{c}\text { Sum of } \\
\text { Squares }\end{array}$ & df & $\begin{array}{c}\text { Mean } \\
\text { Square }\end{array}$ & F & Sig. \\
\hline Regression & .000 & 1 & .000 & .976 & $0.006^{*}$ \\
\hline Residual & .001 & 3 & .000 & & \\
\hline Total & .001 & 4 & & & \\
\hline
\end{tabular}

* The effect is statistically significant at $(\alpha \leq 0.05)$

To validate this hypothesis, the correlation coefficient, the selection coefficient and the regression coefficient were used. The effect is statistically significant at a moral level of (0.05) as shown in table (6).

The results of the statistical analysis shown in the previous table 5 showed a statistically significant effect of the gravitational dimension of the transformative leader on the empowerment of workers of Egyptian tourism companies Category A. The probability value was $(0.006)$, which is below the level of indication $0.05 \%$ where alternative imposition is accepted. This is where the first sub-hypothesis has been proven.

$\mathrm{H} 2$ : There is a statistically significant relationship between inspirational motivation and empowerment of employees within Egyptian tourism companies Category A

\section{Table 7}

Results testing the impact of the motivation on the empowerment of employees.

\begin{tabular}{|l|c|c|c|c|c|}
\hline Model & $\begin{array}{c}\text { Sum of } \\
\text { Squares }\end{array}$ & df & $\begin{array}{c}\text { Mean } \\
\text { Square }\end{array}$ & F & Sig. \\
\hline Regression & .001 & 1 & .001 & 6.151 & $0.029^{*}$ \\
\hline Residual & .000 & 3 & .000 & & \\
\hline Total & .001 & 4 & & & \\
\hline
\end{tabular}

* The effect is statistically significant at $(\alpha \leq 0.05)$.

The results of the statistical analysis shown in the previous table 7 , showed a statistically significant effect of the dimension of the transformative motivation of the transformative leader on the empowerment of workers in Egyptian tourism companies Class A. The probability value was (0.029), which is lower than the level of indication $(0.05 \%)$ where the alternative imposition is accepted. This is where the second sub-hypothesis has been proven.

H3: There is a statistically significant relationship between the intellectual stimulation of the leader and the empowerment of employees within Egyptian tourism companies Category A.

Table 8: 
Results of the test of the effect of intellectual stimulation on the empowerment of workers.

\begin{tabular}{|l|c|c|c|c|c|}
\hline Model & $\begin{array}{c}\text { Sum of } \\
\text { Squares }\end{array}$ & $\mathbf{d f}$ & $\begin{array}{c}\text { Mean } \\
\text { Square }\end{array}$ & F & Sig. \\
\hline Regression & .000 & 1 & .000 & .005 & $0.049^{\mathrm{b}}$ \\
\hline Residual & .001 & 3 & .000 & & \\
\hline Total & .001 & 4 & & & \\
\hline
\end{tabular}

* The effect is statistically significant at $(\alpha \leq 0.05)$.

The results of the statistical analysis shown in the following table (8) showed the effect of the intellectual stimulation dimension of the transformational leader on the empowerment of workers in Egyptian tourism companies Category A.

The probability value of $\left(0.049^{\mathrm{b}}\right)$, which is below the level of indication $(0.05 \%)$ alternative in the following table (9) showed the effect of the dimension of individual considerations of the transformational leader on the empowerment of workers of Egyptian tourism companies Category A.

The probability value of $(0.002)$, which is below the level of indication $(0.05 \%)$ where the alternative imposition is accepted here, the validity of the fourth sub-hypothesis, is clear.

The results of the tables (8), (7), (6), and (5) also indicate that the empowerment of workers is largely linked to the four dimensions of transformational leadership: attractiveness, individual considerations, inspirational motivation, and intellectual stimulation.

This underscores the importance of these dimensions in fostering a sense of empowerment. The result may be due to the ability of the transformative leader to be able to inspire the followers to the highest levels of achievement. This is through the sense of seriousness and importance of the work they perform (Bennis and Nanas, 1997).

The transformational leader's ability to empower workers by providing positive emotional support during crises and pressures to allow employees to experience work. In addition, the transformational leader can empower followers by using words of encouragement, positive persuasion, and acting as a role model (Bass and Avolio, 1993).

2000). This highlights the extent to which the leader's subordinates are accepted as role models. imposition, is accepted. Here, the validity of the third sub-hypothesis is clear.

$\mathrm{H} 4$ : There is a statistically significant relationship between the individual considerations of the transformative leader and the empowerment of employees within Egyptian tourism companies Category $A$

Table 9

Results test the impact of individual considerations on employee empowerment.

\begin{tabular}{|l|c|c|c|c|c|}
\hline Model & $\begin{array}{c}\text { Sum of } \\
\text { Squares }\end{array}$ & df & $\begin{array}{c}\text { Mean } \\
\text { Square }\end{array}$ & F & Sig. \\
\hline Regression & .001 & 1 & .001 & 6.151 & $0.029^{*}$ \\
\hline Residual & .000 & 3 & .000 & & \\
\hline Total & .001 & 4 & & & \\
\hline
\end{tabular}

The results of the statistical analysis shown

It can be said that the leader uses the behavior of inspirational stimulation as it inspires followers to accept and deal with challenges in accordance with the study of (Avolio et al., 2004) where it is also more able to estimate the value of the work. This motivates and encourages followers to achieve their levels, which strengthens their sense of empowerment, as confirmed by the study of (Spreitz, 1995).

These results also reflect the contribution of individual considerations to the prediction of empowerment within Egyptian tourism companies, through the ability of the leader to help his followers develop a sense of self-importance (Bass and Avolio, 1997). These results also reflect the transformative behavior of the leader to encourage followers to participate and take responsibility through listening.

It is clear from previous results that the contribution of the ideal impact on the empowerment of employees of Egyptian tourism companies can be enhanced by saying that the behaviors of the leader should focus on setting high standards and acting as an example. Such behaviors enhance the sense of belonging of followers, and their belief in the importance of their actions and their suitability.

The findings correspond to both (Bass, 1990, Jung; Avolio) 


\section{Table 10}

Pearson Correlation test results to learn how to link transformational leadership and empower employees within Egyptian tourism companies category A

\begin{tabular}{|c|c|c|c|}
\hline \multicolumn{4}{|c|}{ Correlations } \\
\hline & & $\begin{array}{l}\text { Empowering } \\
\text { employees }\end{array}$ & $\begin{array}{l}\text { Transformational } \\
\text { Leadership }\end{array}$ \\
\hline \multirow{2}{*}{$\begin{array}{l}\text { Pearson } \\
\text { Correlation }\end{array}$} & $\begin{array}{l}\text { Empowering } \\
\text { employees }\end{array}$ & 1.000 & .745 \\
\hline & $\begin{array}{l}\text { Transformational } \\
\text { Leadership }\end{array}$ & .745 & 1.000 \\
\hline \multirow{2}{*}{$\begin{array}{l}\text { Pearson } \\
\text { Correlation }\end{array}$} & $\begin{array}{l}\text { Empowering } \\
\text { employees }\end{array}$ & . & .000 \\
\hline & $\begin{array}{l}\text { Transformational } \\
\text { Leadership }\end{array}$ & .000 & . \\
\hline \multirow{2}{*}{$\begin{array}{l}\text { Pearson } \\
\text { Correlation }\end{array}$} & $\begin{array}{l}\text { Empowering } \\
\text { employees }\end{array}$ & 575 & 575 \\
\hline & $\begin{array}{l}\text { Transformational } \\
\text { Leadership }\end{array}$ & 575 & 575 \\
\hline
\end{tabular}

The results of data analysis using Pearson as shown in the following table (10) indicated a correlation between transformational leadership and worker empowerment. The results of the current study are consistent with the results of the studies of (Kark et al., 2003; Avolio et al., 2004; Dust et al., 2014; (O'Zarall, 2003).

Table 11

Results of the transformational leadership test on empowering employees

\begin{tabular}{|l|l|l|c|c|}
\hline \multicolumn{2}{|c|}{ Model Summary ${ }^{\mathrm{b}}$} \\
\hline Model & $\mathbf{R}$ & $\begin{array}{l}\text { R } \\
\text { Square }\end{array}$ & $\begin{array}{l}\text { Adjusted } \\
\text { R Square }\end{array}$ & $\begin{array}{l}\text { Std. } \\
\text { Error of } \\
\text { Estimate }\end{array}$ \\
\hline 1 & $.745^{\mathrm{a}}$ & .555 & .554 & 5.47096 \\
\hline
\end{tabular}

It is clear from the following table (11) that the coefficient link for the independent and dependent variables is (.745a). As can be seen from the table, the R Square selection factor valued at (.555). This means that transformational leadership is explained by $(55.5 \%)$ of the dependent variable. The rest of this ratio is due to other variables that have not been considered and is estimated at (44.5\%).

\section{Discussions}

The results of the study indicated that the degree of exercise of managers to the transformational leadership within Egyptian tourism companies from the point of view of their employees has a Mean of (3.25), which indicates that the majority of employees are members of the sample. This is illustrated by the behavioral practices of their managers, which reflect the leadership practices of transformational leadership. This gives a positive impression of their attitude towards the prevailing leadership style.
The dimension of attractiveness of transformative leadership ranked first with an average (22.03). This shows that the administrative leaders within the Egyptian tourism companies Category A focus on core values, justice, and respect when dealing with affiliates. The inspirational motivation came in second place with an average (21.75). This shows that the administrative leaders within the Egyptian tourism companies Category A motivate workers by acting as role models. These dimensions represent the charismatic side of the transformative leader (transformational leadership) (Bass and Avilio, 1994).

The study demonstrated the association of transformative leadership with all dimensions of empowerment - which are studied - namely, competence, autonomy, and influence.

4-The study highlighted that there is a statistically significant effect of the dimension of the transformative leader's motivation to enable workers of Egyptian tourism companies Category $\mathrm{A}$, where the probability value was (0.029).

The study proved that there is a statistically significant effect of the dimension of attractiveness of the transformative leader on the empowerment of workers in Egyptian tourism companies Category A, where the probability value was (0.006), which is below the level of indication $(0.05 \%)$.

The study revealed that there are statistically significant differences between the study sample responses in terms of the leader's inspirational stimulation as one of the dimensions of the study. The differences were in favor of age from 41 to 60 , followed by 26 to 40 , followed by less than 26 .

The study showed that tourism companies Category A employs university graduates (bachelor or bachelor's degree) by a large percentage of more than $70 \%$. This is a positive indicator that enables companies to benefit from their scientific knowledge.

This study found that the age group that is predominantly employed in Egyptian tourism companies is the youth group. The number of people aged 26 to under 40 was $50.8 \%$.

From this study it became clear that all the members of the sample agreed that the leader has charismatic attributes that make him admired by others. The responses of the sample members indicate that this is achieved with a ratio 
weight of (.898) and an average calculation of (4.4922).

The study showed that empowerment leads employees to take risks and enhance their performance by gaining greater autonomy and selfresponsibility. The transformative behavior of the leader encourages followers to participate and take responsibility through listening.

\section{Conclusion and Recommendations}

As the most important source of success and excellence, human resource is a strategic resource that, when invested, creates added value to the organization. It improves its performance when it is empowered and cared for and achieves continuity and growth.

This is also where transformational leadership intervenes to provide workers with the climate to blow up and exploit their energy, and to perform high-quality work. Empowerment is a source of leadership power. As a result of the above, the main theme problem has been raised, which has crystallized about the extent of the impact of transformational leadership on the empowerment of employees of Egyptian tourism companies Category A.

In order to test the relationship between transformational leadership and empowerment of workers within Egyptian tourism companies, the researcher prepared a questionnaire and distributed it to a random sample of employees of Egyptian tourism companies Category A. In order to reveal the extent to which the dimensions of transformational leadership are applied to these companies and their role in empowering employees.

Based on the problematic topics discussed through the theoretical study in which we discussed both the topics of transformational leadership and the empowerment of workers and the theoretical relationship between them, as well as through the practical chapter, which served as a case study of the reality of the impact of transformational leadership on the empowerment of employees of Egyptian tourism companies Category A.

First: Recommendations addressed to human resources management (training department)

1. Work on the development of transformational leadership skills and this mechanism can be implemented by:

2. Leaders should support workers and encourage them to take responsibility for the crises and risks that the company may face and know how to deal with these crises, considering the tourism sector as a highly sensitive sector.

3. -Full support for the creative and intellectual sense of employees by the leaders.

4. Encourage followers to participate and take responsibility by listening.

Second: Recommendations addressed to human resources management (recruitment section)

1. Relying on the transformational leaders in the management of resources and tourism institutions so that they are able to motivate their followers and this mechanism can be implemented through the following:

2. Putting the dimensions of transformational leadership within the performance evaluation criteria to encourage managers to improve and develop it.

3. Set some questions that measure the level of transformational leadership of new job candidates within tourism institutions.

Third: Recommendations addressed to senior and middle management and human resources management of tourism institutions and administrative leaders

1. Focus on the external causes of the organizational change process if management wishes to make actual changes.

2. Relying more on transformational leadership dimensions to focus on organizational change and being a successful one.

3. Devolving powers to enable management leaders to motivate employees and to take care of the formation of management frameworks that take transformational leadership as a work practice, which has a positive impact on the achievement of organizational justice in the working environment.

\section{References}

Arnold, K. A., and Loughlin, C. (2013). Integrating transformational and participative versus directive leadership theories: Examining intellectual stimulation in male and female leaders across three contexts. Leadership and Organization Development Journal 34(1), 67-84. http://doi.org/10.1108/01437731311289974.

Avolio, B. J., Walumbwa, F. O., and Weber, T. J. (2009). Leadership: current theories, research, and future directions. Annual Review of Psychology, 60, 421-49.

Avolio, BJ, Zhu. W, Koh, W., and Bhatia, P. (2004). Transformational leadership and organizational 
commitment: Mediating role of psychological empowerment and moderating role of structural distance, Journal of Organizational Behavior 25, 951-968.

Bass, B. M. (1998). Transformational leadership: Industrial, military, and educational impact. Mahwah, NJ: Erlbaum.

Bass, B. M., and Riggio, R. E. (2006). Transformational leadership ( $2^{\text {nd }}$ ed.). New York: Psychology Press.

Bass, B. M., Avolio, B. J., Jung, D. I. and Berson, Y. (2003). Predicting unit performance by assessing transformational and transactional leadership. Journal of Applied Psychology, 88(2), 207-218. doi: 10.1037/0021- 9010.88.2.207.

Bass, B.M., Daniel, L.G., and Tucker. M.L. (1992). Transformational leadership's impact on higher education satisfaction, effectiveness, and extra effort. In Clark KE (Ed), Impact of leadership, Leadership Library of America, West Orange NJ.

Bennis, W., and Nanus, B. (1985). Leaders, Harper and Row. New York, NY.

Carlson, D. S. and Perrewe, P. L. (1995). Institutionalization of organizational ethics through transformational leadership. Journal of Business Ethics, 14, 829-838.

Conger, J. A. and Kanungo, R. N. (1998b). Charismatic leadership in organizations. London: Sage.

Conger, J. A. (1999). Charismatic and transformational leadership in organizations: An insider's perspective on those developing streams of research. Leadership Quarterly, 10(2), 145-170.

Doaei, H. (1998). Human Resource Management, Publishing of Ferdousi University in Mashhad.

Gillespie, N.A., and Mann, L. (2004). Transformational leadership and shared values: the building blocks of trust. Journal of Managerial Psychology 19(6), 588607.

Gumusluoglu, L., and Ilsev, A. (2009). Transformational leadership, creativity, and organizational innovation, Journal of Business Research, 62 (4), 461-473.

Judge, T. A., and Piccolo, R. F. (2004). Transformational and transactional leadership: A meta-analytic test of their relative validity. Journal of Applied Psychology, 89(5), 755-768. doi: 10.1037/0021-9010.89.5.755

Kotter, J. P. (1996). What leaders really do. In R. M. Steers, L. W. Porter and G. A. Bigley (Eds.), Motivation and leadership at work, New York: McGraw-Hill, 620-627.

Lim, B.-C., and Ployhart, R. E. (2004). Transformational Leadership: Relations to the FiveFactor Model and Team Performance in Typical and Maximum Contexts. Journal of Applied Psychology, 89(4), 610-621. https://doi.org/10.1037/00219010.89.4.610
MacKenzie, S.B., Podsakoff, P.M., and Rich, G.A. (2000). Transformational and transactional leadership and salesperson performance. Journal of the Academy of Marketing Science 29(2), 115-134.

McCann, R. M., Ota, H., Giles, H., and Caraker, R. (2003). Accommodation and non-accommodation across the lifespan: Perspectives from Thailand, Japan, and the United States of America. Communication Reports, 16, 69-91.

Meyer, J., and Allen, N. J. (1997). Commitment in the workplace: Theory, research and application. Thousand Oaks, CA: Sage.

Northouse, P. G. (2013). Leadership: theory and practice (6th ed.). Los Angeles: Sage publications, Inc.

Northouse, Peter G. (2001). Leadership Theory and Practice, 4th edition. Thousand Oaks, CA: Sage Publications, Inc.

Podsakoff, P.M., MacKenzie, S.B., Moorman, R.H., and Fetter, R. (1990). Transformational leader behaviors, and their effects on followers' trust in leader, satisfaction, and organizational citizenship behaviors, Leadership Quarterly 1(2), 107-142.

Spreitzer, G. (1995). Psychological empowerment in the workplace: dimensions, measurement, and validation. Academy of Management Journal, 38(5), 1442-65.

Spreitzer, G.M., Perttula, K.H. and Xin, K. (2005). Traditionality matters: An examination of the effectiveness of transformational leadership in the United States and Taiwan, Journal of Organizational Behavior 26, 205-227.

Stone, P. (1992). Transformational leadership in principals: An analysis of multifactor leadership questionnaire results, Professional leadership development monograph series, 2(1), Mankato State University, MN.

Yammarino, F. J., Dionne, S. and Chun, J. U. (2002). Transformational and charismatic leadership: A levels-of-analysis review of theory, measurement, data analysis, and inferences. In L. L. Neider and C. A. Schriesheim (Eds.), Leadership Greenwich, CT: Information Age Publishing., 23-63. 